УдК 537.633 .9

V.T. Chemerys, Cand. Sci. (Techn.)
National Aviation University of Ukraine
(Ukraine, 03680, Kyiv, Cosmonaut Komarov Ave., 1,
e-mail: vchemer@gmail.com)

\title{
Contact Surface Resistivity as a Favorable Condition of Commutation Process
}

It is shown on the basis of analysis for electrotechnical model of commutation process in the contact zone of rail accelerator of macrobodies that surface resistivity of electrodes of a contact pair is a necessary condition for favorable commutation of current in electromechanical transducers with a sliding contact. In the model of accelerator which has the increasing resistivity of the rail surface layer along with the rise of armature motion velocity it is shown that the volume Joule's losses in the skin layer per unit of rail length can be constant in spite of its resistivity growth, so causing no additional superheating of the conductor. A discussion is performed concerning similar situation in the rotating commutator machines.

Ke y w o r d s: sliding contact of machines, problems of commutation, resistivity of contact surface, application in rail accelerator, similarity with rotational machines.

На основе анализа электротехнической модели коммутационного процесса в контактной зоне рельсового ускорителя макротел показано, что резистивный характер поверхности электродов контактной пары является необходимым условием, способствующим коммутационному процессу в электромеханических преобразователях со скользящим контактом. Для модели ускорителя, имеющей возрастающее удельное сопротивление поверхностного слоя рельсов по мере возрастания скорости движения якоря, показано, что объемные джоулевы потери на единицу длины скин-слоя рельсов могут оставаться неизменными, не вызывая дополнительного перегрева проводника в скин-слое в связи с увеличением его удельного сопротивления. Подобная ситуация рассмотрена для электрических машин вращательного движения.

Ключе в ы е сло в а: электромеханические преобразователи, скользящий контакт, коммутация, резистивный поверхностный слой, рельсовый ускоритель, машины вращательного движения.

Introduction. Electrical machines with a sliding contact continue to have the popular application both in the field of micro-machines and in the field of the giant energy, when it is necessary to create a powerful catapult or rail accelerator at mega-ampere current. The nature of commutation process is common for all types of electromechanical energy converters with sliding electric contact. A displacement of a moving electrode and a tendency to breaking of current in the

(C) V.T. Chemerys, 2017 


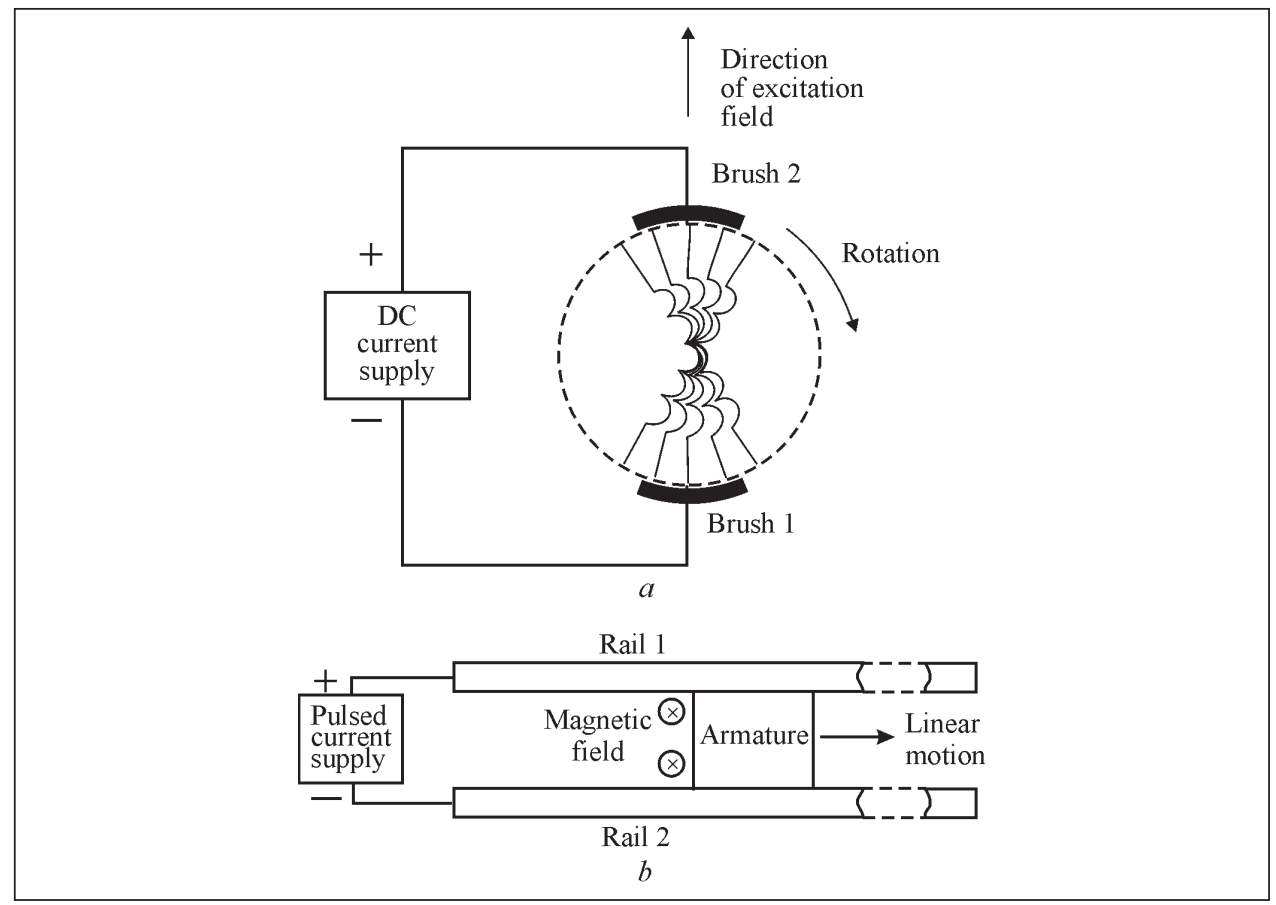

Fig. 1. The principal scheme of commutation in the rotating commutator machine $(a)$ and of rail accelerator of macrobody with linear motion of armature as continuous commutation process $(b)$

circuit gives birth to a necessity to provide a fast dissipation of some electromagnetic energy stored in the elements of commutated circuit.

The analytical and numerical investigation of commutation process in the rail accelerator with variable resistivity of surface layers of contact gave a possibility to propose a generalized view on the commutation process and on the needed condition for the favorable operation of contact. Taking into account the required resistive properties of contact surfaces it is possible to propose the special design of rails to exclude the rail destruction by electric arc in the process of armature motion in the rail accelerators. The paper proposes the commutation analysis of armature motion.

A general scheme of commutation process in the machine. For any kind of machine with sliding contact the main goal of commutation process is to keep constant a direction and value of current in some elements of the moving part of machine. This process is illustrated in Fig. 1, $a$, for the machine of rotational motion and in Fig. 1, $b$, for the machine of linear motion. The common property of both schemes is the exchange of one current-carrying element of a moving part by the next element, and time of the presence of the former one in the circuit of 


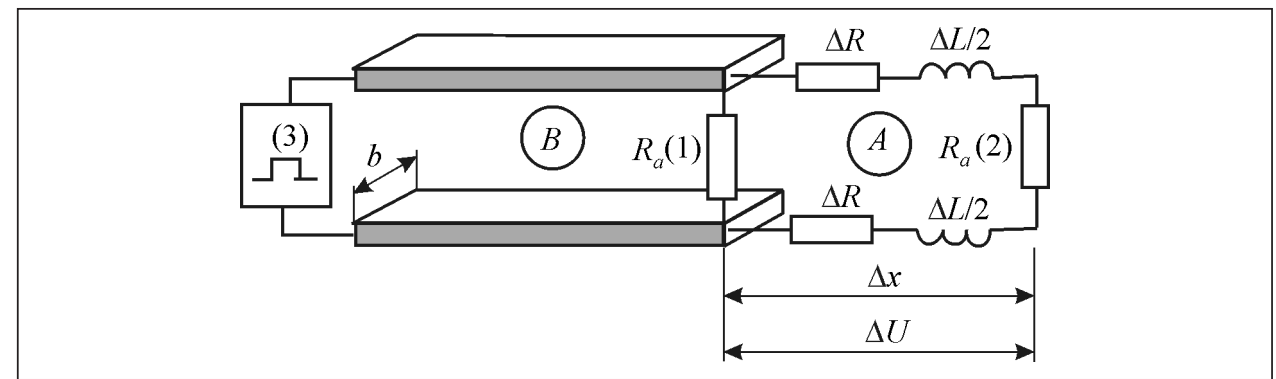

Fig. 2. Sketch of electrical model for commutation analysis of rail accelerator: 1 - armature resistance $R_{a}$ before displacement; 2 - armature resistance $R_{a}$ after displacement at the distance $\Delta x ; 3$ - pulsed current supply

current is limited. Taking part in the current passage the current-carrying element can store some value of magnetic energy due to the existence of its inductance. Following the known laws of commutation this energy cannot disappear with the exit of the element under consideration out of the current circuit.

That is why the element exit out of contact zone with a tendency to fast breaking of current gives birth to appearance of extra-voltage as a result of the fast drop of magnetic flux linked with this element of moving secondary part of machine. In case of small length of the contact zone at rotating machine this extra-voltage leads to creation of electric arc through the air gap to support the existence of current, while the stored magnetic energy needs time for dissipation. Probably, that is rational to increase the contact zone length to provide a possibility for a decrease of extra-voltage due to dissipation of magnetic energy in the massive unmovable electrode of pair.

Electrotechnical analysis of commutation process. The analytical consideration of commutation process from the position of electrical engineering can be performed simple enough in the model of linear motion of armature (Fig. 1,b). This model corresponds to the of contact zone configuration in the rail accelerator of macrobodies [1]. For the analysis of extra-voltage appearance it is possible to consider the equivalent scheme of circuit shown in Fig. 2. As a result of the elementary displacement of armature at the distance $\Delta x$ into the existing circuit an element of resistance $\Delta R$ and element of inductance $\Delta L / 2$ (per one side of the contact zone) must be added. If the power supply is able to support the current value in spite of the variation of circuit parameters it is natural that new added elements of the circuit will be under the action of extra-voltage jump $\Delta U=\Delta(L I) / \Delta t \approx$ $\approx I(\Delta L / 2) / \Delta t$, where $\Delta t$ is the time of armature displacement at the distance $\Delta x$. The model will be more adequate, if we shall take into account the real law of current variation in time stipulated by power supply: $I(t)=I_{\max }[1-\exp (-t / T)]$, 
where $T \approx 0.5 \mathrm{~ms}$ is a typical time of current increase in the rail accelerator, the amplitude meaning $I_{\max }$ can be accepted at the level of 1 MA. Thus for the extra-voltage $U_{\text {ex }}$ the equation should be written as follows:

$$
U_{\text {ex }}=I(t)[\Delta R+(\Delta L / 2) / \Delta t]+(\Delta L / 2) \Delta I(t) / \Delta t .
$$

The parameter $(\Delta L / 2)$ can be calculated at known inductance of rails system per unit of length $L^{\prime}=\Delta L / \Delta x[\mathrm{H} / \mathrm{m}]$ as $(\Delta L / 2)=L^{\prime} \Delta \mathrm{x}$. The parameter $\Delta R$ can be calculated using information about formation of skin layer depth in time $\delta(t)=$ $=(D \cdot \Delta t)^{1 / 2}$, where $D=(\mu \sigma)^{-1}$ is a coefficient of the field diffusion into the rail material. Finally the resistance of the rails part under switching on will be $\Delta R=$ $=\Delta x /(\sigma \delta b)=v /\left(\delta b v_{D}\right)$, where the next values have been used: velocity of armature displacement $v=\Delta x / \Delta t$; speed of the field diffusion into material of rail $v_{D}=D / \delta=\delta / \Delta t$; a width of current layer in rail $b$ (see Fig. 2). The full time of armature motion from the start position $t_{k}$ can be expressed via discrete meaning in function of elementary step of displacement number $k$ in assumption that the armature motion has the constant acceleration $a \approx 5 \cdot 10^{5} \mathrm{~m} / \mathrm{s}^{2}$, so the time is connected with the length of the path passed by armature $S_{k}=k \Delta x$ is $t_{k}=(2 k \cdot \Delta x)^{1 / 2}$. Then for current we have a time dependence

$$
I\left(t_{k}\right)=I_{\max }\left[1-\exp \left(-t_{k} / T\right)\right],
$$

and for motion velocity $v(k)=(2 a k \Delta x)^{1 / 2}$. After substitution of all values into equation (1) it is possible to derive the needed dependence of electrical conductivity on the path passed by armature using the condition that extra voltage $U_{\text {ex }}$ must be less than ultimate value $U_{b r}$ that can be a guarantee of the absence of electrical breakdown through the air along the surface of new switched on elements of the rail. From the equality $U_{\mathrm{ex}}=U_{b r}$ the next expression follows:

Finally

$$
\sigma(k)=\left(\mu \Delta t / b^{2}\right)\left[U_{b r} /(I(k) v(k))-\left(L^{\prime} / 2\right)\right]^{-1 / 2} .
$$

$$
\begin{gathered}
\sigma(k)=\left(\frac{2 \Delta x}{a}\right)^{1 / 2}\left[(k+1)^{1 / 2}-k^{1 / 2}\right] b^{-2} \times \\
\times\left\{\frac{U_{b r}}{I_{\max }\left[1-\exp \left(-(1 / T)(2 k \Delta x / a)^{1 / 2}\right)\right](2 a k \Delta x)^{1 / 2}}-\frac{L^{\prime}}{2}\right\}^{-2} .
\end{gathered}
$$

The expression (2) has been illustrated by graphs in Fig. 3 with the next fixed parameters: $T=0.5 \mathrm{~ms}, \mathrm{~L}^{\prime}=10^{-6} \mathrm{H} / \mathrm{m}, a=5 \cdot 10^{5} \mathrm{~m} / \mathrm{s}^{2}, I_{\max }=10^{6} \mathrm{~A}, b=$ $=0.04 \mathrm{~m}, \mu=\mu_{0}=1.26 \cdot 10^{-6} \mathrm{H} / \mathrm{m}, U_{b r}=(30, \ldots, 400) \mathrm{V}, \Delta x=0.01 \mathrm{~m}$. 


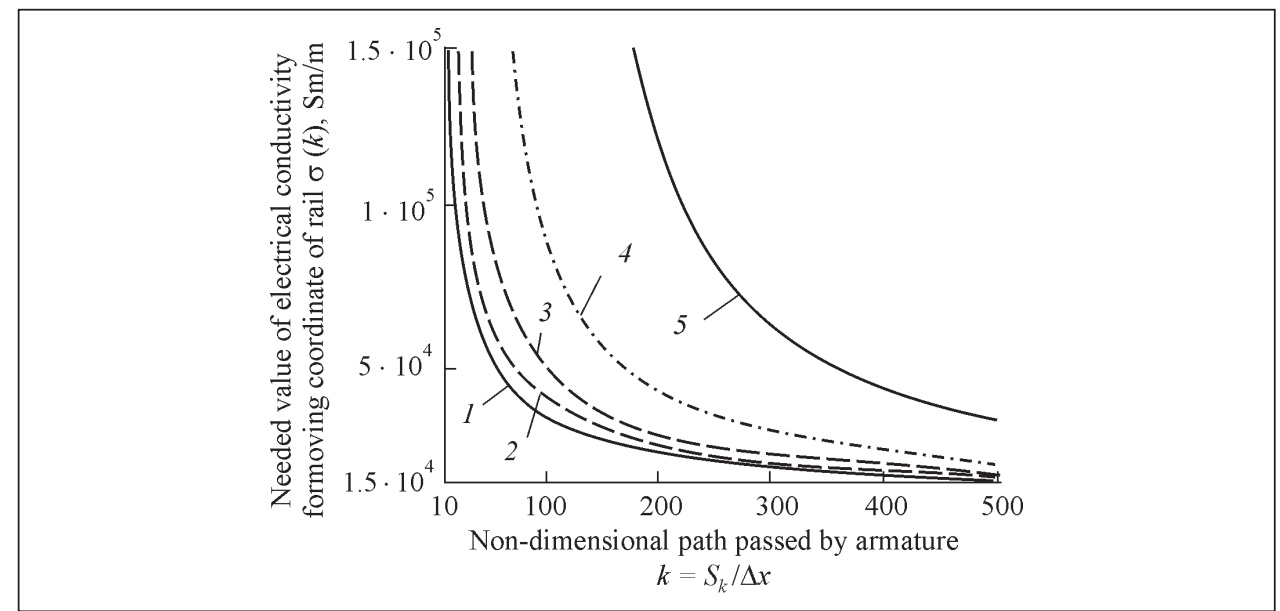

Fig. 3. Electrical conductivity of rails calculated by (2): The horizontal axis gives the running coordinate of rail along with armature motion: $1-U_{b r}=30 \mathrm{~V} ; 2-U_{b r}=60 \mathrm{~V} ; 3-U_{b r}=100 \mathrm{~V}$; $4-U_{b r}=200 \mathrm{~V} ; 5-U_{b r}=400 \mathrm{~V}$

The velocity of armature which corresponds to accepted data of acceleration is shown in the graph in Fig. 4. It is clear from consideration of Fig. 2 that for reduction of extra-voltage up to $60 \mathrm{~V}$ it is necessary to decrease the electrical conductivity of rails below $5 \cdot 10^{4} \mathrm{Sm} / \mathrm{m}$ beginning from $k \approx 80$, i.e. after the path passed by armature less than $0.8 \mathrm{~m}$. To avoid the extra-voltage at this level under the increase of armature velocity up to $2 . .2 .5 \mathrm{~km} / \mathrm{s}$ it is necessary to decrease the rails conductivity up to $(1 \ldots 2) \cdot 10^{4} \mathrm{Sm} / \mathrm{m}$.

Estimation of Joulse's losses in the rail elements. To derive the final decision about acceptability of reduction of extra-voltage stipulated by continuous commutation process it is necessary to make an estimation of Joule's heat generated in the skin-layer of rail by pulsed current. For estimation we shall neglect the change of current and velocity during time interval $\Delta t=\Delta x / v$. Thus Joule's heat generated in the volume of skin-layer of rail for a length $\Delta \mathrm{x}$ at the $k$-step of armature motion will be

$$
Q_{\text {Joule }}=I^{2}(k) \Delta R(k) \cdot \Delta t_{k}=\left(I^{2} \Delta x / b\right)[\mu \cdot \Delta x /(\sigma \cdot v)]^{1 / 2} .
$$

When deriving the formula (3), the expressions for $\Delta R$ and $\Delta t_{k}$ introduced above have been used. The main sense of (3) consists in the principal possibility to keep Joule's heat constant along all the elements of rails at $\sigma \cdot v=$ const, because the length of element $\Delta x$ is fixed here. And what about the local heat losses per unit of volume in the skin-layer of rail? Due to the decrease of the skin-layer depth and due to the shortening of current passage along the element $\Delta x$ along with its number $k$ the local heat losses per unit of volume in the framework of our 


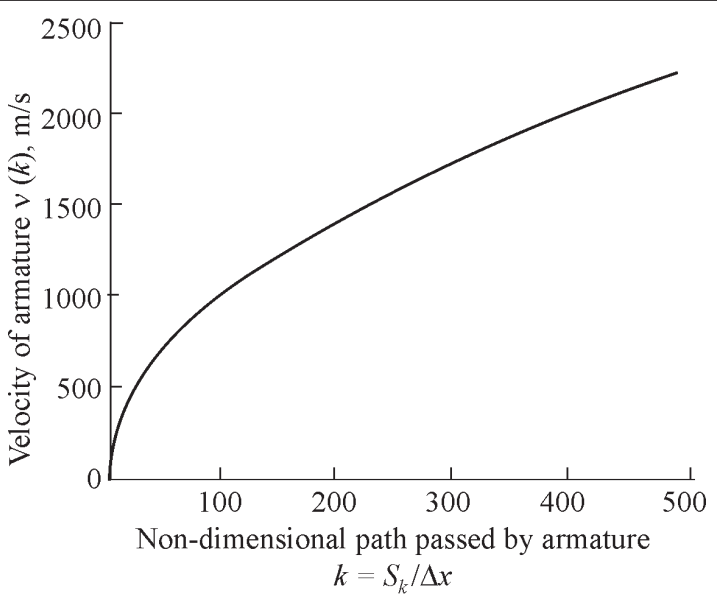

Fig. 4. An armature velocity as a function of non-dimensional coordinate measured along the rail

consideration will depend neither on the armature velocity nor on the local electrical conductivity of skin-layer and will only depend on the current variation. To be sure it is enough to calculate the local losses $q=Q_{\text {Joule }} / V_{s k}$, where $Q_{\text {Joule }}$ is given by (2) and $V_{s k}$ is the volume of rail conductor in the skin-layer of one element of length: $V_{\text {skin }}=b \delta \Delta x$. Calculation yields to result:

$$
q=\left(I^{2} \Delta x / b\right)[\mu \cdot \Delta x /(\sigma \cdot v)]^{1 / 2} \cdot(b \cdot \delta \cdot \Delta x)^{-1}=\mu(I / b)^{2} .
$$

Thus, the proposed method of extra-voltage damping in the rail accelerator due to the decrease of rail electrical conductivity along with the growth of armature motion does not bring a threat of super-heating of skin-layer in rail. It is possible due to general stability of local heat losses per unit of conductor volume. At the same time the reduction of electrical conductivity according to (2) creates a favourable condition for the dissipation of magnetic energy in the resistive skin-layer of rails during armature transportation.

Discussion of results and their application to rotating machines. The comparison of expressions (2) and (3) displays that the condition for essential reduction of extra-voltage (2) is more strong than the condition for provision of stable distribution of heat losses along the rail length $\sigma v=$ const in (3). Moreover, in (3) the heat losses per one element of the rail length $\Delta x$ do not depend on the accepted value of ultimate extra-voltage $U_{b r}$. The increase of velocity (see Fig. 4) is given by expression $v(k)=(2 a k \Delta x)^{1 / 2}$, so for a constant meaning $Q_{\text {Joule }}$ in (3) it would be enough to save $\sigma(k)=$ const $\cdot(2 a k \cdot \Delta x)^{-1 / 2}$ that is not necessary to satisfy the condition (2) for limitation of extra-voltage. Thus at the choice of the law of conductivity distribution in (2) for low meaning of extra-voltage $\left(U_{b r}=30 \ldots 60 \mathrm{~V}\right)$ the value of heat losses $Q_{\text {Joule }}$ per element of rail length $\Delta x=$ $=$ const can be growing as a result of $\sigma v$ decrease in (3) in comparison with $\sigma v=$ 
$=$ const. The final law of conductivity distribution along the rail must be taken with allowance for the full set of factors as the ultimate extra-voltage, allowable heating of skin-layer, except for the condition for arc creation. In any case the conclusion about a positive role of the rail contact surface resistivity retains its significance.

Concerning rotational machines we see some analogy of commutation process jointly with some differences. Results of analysis made for rail accelerator can be directly applied only to homopolar machine with a solid cylindrical rotor. Respectively, in Fig. 1, $a$, the excitation field direction should be changed by the axial one, and the currents of rotor should be implied as those directed along the radius (or diameter for 2-pole system) of the cylinder. The surface of homogeneous massive of the rotor will behave like the rail contact surface in Fig. 1, b, with corresponding peculiarity of commutation process due to the brushes disposed in the zone of the excitation field.

In application to traditional commutator motor we must imply in Fig. 1, $a$, that the winding of rotor is manufactured as a set of frames of wire, which active sides are directed along the machine axis. Specificity of traditional machines consists of disposition of commutator system out of the zone of excitation field. A discrete character of lamella contact with a brush gives birth to division of commutation process into separate parts. The first one is current excitation through an inductive circuit of the rotor winding section with the increase of flux linkage of this section. The next one is the useful work of current-carrying section with creation of electrodynamics force and torque. The last part is leaving of contact with a brush with reducing the section flux linkage. That proceeds gradually due to the contact surface shortening in time, and at this stage of the process we meet the same necessity of stored magnetic energy dissipation at switching off the current of the winding section. Namely in this part of commutation process a conclusion about the useful role of the brushes resistivity can be applied. That is why the brushes are mainly manufactured not from perfect conductor but from graphite not only due to its anti-friction properties but also due to its low (in comparison with copper) electrical conductivity that is useful for the quenching of electrical arcing. In the motor design the important role belongs to the angle between the excitation field direction and direction of radial line of brush symmetry. Tuning of this angle gives a possibility to regulate a time duration of the last part of commutation process (leaving of contact) to avoid too high drop of flux linkage of commutated section of winding.

Conclusion. The work presented in this paper can be evaluated as the further development of the idea of isotropic layers at the rails described in the paper [2] by Yu.A. Dreisin. The result of our analysis shows that the surface layer resistance must be variable along the rail depending on the armature velocity. In Princeton's small railgun [3] a model with graphite rails was tested successfully. In the NAVY Res. Lab. research [4] as well as in the previous investigations [5] 
great attention was devoted to metallurgical aspects of the rail wear to provide their stability. Later the multi-layer cover of rails by layers of low variable conductivity has been investigated in [6]. Besides the possibility to reach a reduction of extra-voltage at commutation process the multi-layer cover of rail allows improving the current distribution along the contact zone and avoiding the current concentration at the trailing edge of armature caused by "velocity skin effect". It was demonstrated in [6] by the method of mathematic simulation in COMSOL.

На основі аналізу електротехнічної моделі комутаційного процесу в контактній зоні рейкового прискорювача макротіл показано, що резистивний характер поверхні електродів контактної пари $є$ необхідною умовою сприяння комутаційному процесу в електромеханічних перетворювачах з ковзаючим контактом. Для моделі прискорювача, що має зростаючий питомий опір поверхневого шару рейок в міру збільшення швидкості руху якоря, з'ясовано, що об'ємні втрати енергії на джоулеве тепло в розрахунку на одиницю довжини скінового шару рейок можуть залишатися незмінними, не викликаючи додаткового перегрівання провідника у скіновому шарі через зростання його питомого опору. Розглянуто роль резистивного характеру матеріалу електродів контактної пари в електричних машинах обертального руху.

Ключ о в і сло в а : електромеханічний перетворювач, ковзаючий контакт, комутація, резистивний поверхневий шар, рейковий прискорювач, машини обертального руху.

\section{REFERENCES}

1. Chemerys, V.T. (2013), Key problems of railgun: New conception for their resolution, Procedia Eng., Vol. 58, pp. 377-383.

2. Dreisin, Yu.A. (1993), Solid armature performance with resistive rails, IEEE Transactions on Magnetics, Vol. 29, no. 1, pp. 798-803.

3. Romalis, M., Nelson, P., Ercal, D. et al. Physics 210 rail gun project, available at: https:// www.princeton.edu/ romalis/PHYS210/railgun/railgun.html.

4. Cooper, K.P., Jones, H.M. and Meger, R.A. (2006), Metallurgical analysis of railgun material, Report of NAVAL Res. Lab., Proceedings of the 13th IEEE EML Symposium, Brandenburg, Germany, May 2006, available at: citeweb.info/20010817794.

5. Persad, C., Lund, C.J. and Eliezer, Z. (1989), Wear of conductors in railgun: metallurgical aspects, IEEE Transactions on Magnetics, Vol. 29, no. 1, pp. 433-437.

6. Chemerys, V.T. (2015), Rail accelerator as continuous commutation process, IEEE Transactions on Plasma Science, Vol. 43, no. 3, part II, pp. 869-877.

Received 10.04.17

CHEMERYS Volodymyr Terentiyovych, Cand. Sci. (Techn.), senior scientist, associate professor at the Department of Theoretical and Applied Physics of the National Aviation University of Ukraine. $V$. Chemerys graduated from the National Technical University of Ukraine "Kyiv Polytechnic Institute" in 1962. In 1973 he took his Candidate's degree in energy conversion at the Institute of Electrodynamics of the Academy of Science of Ukraine. The field of scientific research: pulsed electromechanical energy conversion, physics of pulsed electrodynamic systems. 